\title{
The Role of Government and Markets in the Strategy "Europe 2020" of the European Union: A Robust Political Economy Analysis
}

\begin{abstract}
"There is no other choice: government either abstains from limited interference with the market forces, or it assumes total control over production and distribution. Either capitalism or socialism; there is no middle of the road." [L. v. Mises, 1976/1996, p. 26].

"To imagine that the economic life of a vast area comprising many different people can be directed or planned by democratic procedure betrays a complete lack of awareness of the problems such planning would raise. Planning on an international scale, even more than is true on a national scale, cannot be anything but a naked rule of force, an imposition by a small group on all the rest of that sort of standard and employment which the planners think suitable for the rest." [F.A. v. Hayek, 1944/2006, p. 229].
\end{abstract}

\begin{abstract}
The EU's current ten year strategy "Europe 2020" aims to set out a vision of a European social market economy for the 21 st century that will promote economic growth with social and ecological attributes. This article analyzes the roles ascribed to the government and the market and the extent this role allocation is suitable to enhance growth of the European Union's member states. Based on a robust political economy framework it is argued that this new economic policy concept is in essence a technocratic approach and a form of selective interventionism. As such it suffers from three major shortcomings: (1) it underestimates the difficulties of gathering and analyzing the relevant information necessary for steering the economy in the desired direction, (2) it encourages rent-seeking rather than productive entrepreneurship, and (3) it may cause a subtle transformation of the societal


order through the diminution of individual liberties. It is contended that while an interventionist policy approach meets the preferences of large parts of the population, not the least in Germany, it is unlikely to boost economic growth and employment in the EU.

Keywords: European Union, economic development, robust political economy, Austrian economics

JEL: B 53, D 72, H 77, P 50

\section{Introduction}

On June 17, 2010 heads of the European Union governments passed a new long-term growth agenda for the next 10 years called "Europe 2020: A strategy for smart, sustainable and inclusive growth," as a follow-up program to the Lisbon-Strategy of 2000. The declared objectives of "Europe 2020" are overcoming the euro and debt crisis and preparing the European Union (EU) for the next decade by fostering economic growth, and a high level of employment and productivity, as well as social cohesion and ecological sustainability. In doing so, according to the then-president of the European Commission José Manuel Barroso, "Europe 2020" attempted to set out and implement a vision of a European social market economy for the $21^{\text {st }}$ century.

A central and controversial question is the appropriate role of government in promoting economic growth. The goal of this article is to analyze the role that "Europe 2020"attributes to the government, European institutions and markets and the extent that these roles will offer Europe new economic perspectives and enhance their growth performance. In this analysis we rely on a robust political economy framework, which allows checking the feasibility of policy approaches by examining (1) whether the economic and political actors are able to gather and analyze the relevant information necessary for achieving the desired goals (knowledge problem); and (2) if they have the incentives to refrain from destructive rent-seeking behaviour (incentive problem).

The remainder of the article is organized as follows: Next section develops the notion of robust political economy. Following section highlights the major goals and policy instruments of "Europe 2020" in order to identify the main features of the proposed economic policy concept. Later the robustness of that policy concept, and its possible implication for the economies of its member states with a particular focus on Germany, which economically is the most powerful EU member country and a key player in the on-going eurozone crisis, are discussed. The model of a social market economy to which Barroso referred in EU's current ten year growth strategy has its origin in this country. Therefore, Germany suggests itself as a reference model. The paper ends with concluding remarks. 


\section{The Robust Political Economy Framework}

The robust political economy framework has been developed by Boettke and Leeson [2004], Leeson and Subrick [2006] and Pennington [2011a and 2011b]. They have synthesized major insights of the Austrian School of Economics, Public Choice Theory and Institutional Economics into a unified analytical framework for evaluating economic policies and institutional designs. Here robustness is understood as resilience and a criterion by which policies can be assessed by testing their performance in real-world situations across time and space where human beings are imperfect. In the ideal neoclassical world, policy-makers are both omniscient and benevolent social wealth maximizers. They have the knowledge to find optimal economic policies and do not hesitate to pursue them. Robust political economy requires checking the feasibility and desirability of a policy approach in the face of conditions that deviate from the ideal neoclassical assumptions of perfect knowledge (omniscience) and benevolence.

The assumption of omniscience was questioned in the literature by the most prominent representatives of the Austrian School of Economics - Ludwig von Mises [e.g. 1920] and Friedrich August von Hayek [1945] - and the assumption of government benevolence by the Public Choice School of economics, particularly James Buchanan and Gordon Tullock (see e.g. Buchanan et al., 1980). Institutional economists [e.g. North; Olson, de Soto, Acemoglu and Robinson] have shown that when market and political actors have imperfect knowledge and motivations, wealth creation relies on the right rules of the game as they structure the incentives underlying individual action [Pennington, 2011b, p. 2; Boettke and Fink, 2011, p. 2f]. The institutional environment thus determines if people engage in productive, unproductive, or destructive behaviour [Baumol, 1990; Boettke and Coyne, 2009].

Hence, there are two central problems that all policy recommendations have to address: (1) the knowledge problem, and (2) the incentive problem of decision-makers to implement policies that increase welfare. The first problem addresses the question: Even if individuals are assumed to be benevolent, how will they obtain the information needed to make the right decisions in any given situation? With regard to the overall goal of "Europe 2020" the question is who has the knowledge necessary to promote smart, sustainable and inclusive growth - scientists and politicians or private entrepreneurs? The central question underlying the second problem is: Given that policy-makers and private businessmen are "omniscient," what incentives do they face in making their decision? [Boettke and Leeson, 2004, p. 101]. Since the incentives for political and economic actors are shaped by the institutions (rules of the game) the way they are arranged is crucial to achieve robustness. These institutions should constrain self-interested policy-makers in such a way that they cannot do much harm, if they only strive to maximize their own utility and if they possess only limited information. Following the insight of Hayek this 
ability can best be achieved if rules are universalizable. This requires that rules apply to an unknown number of persons, do not prescribe certain behaviours, merely prohibit a finite number of actions, and are unequivocally clear about the legality of those actions [Hayek, 1973, p. 73]. If institutions have these traits, it is less likely that interest groups will be able to receive privileged treatment at the detriment of society because legislation promising this will be impossible. At the same time, they ensure the openness of the entrepreneurial discovery process.

According to this analytical framework, the economic policy concept of "Europe 2020" is only robust, if the proposed goals are not undermined by either difficulties in capturing the information required to achieving those goals (knowledge problem) or/and by the self-interested behaviour of individual actors gaming the system to their own advantage (incentive issues). Or, as Moberg puts it, "a robust political economy is an institutional set-up that yields beneficial outcomes despite the flaws of policy makers and people in business" [2014, p. 3f].

Of course, testing for robustness need not be limited to issues of actor information and motivation, but can include additional aspects, e.g. socio-political or ethical challenges [Pennington, 2011b] to test what implications policy measures may have on individual freedom and democracy or on the moral attitudes of a certain society and its individuals forming it. Arguments in this context have also been put forward by Hayek, Mises [Pies, 2010, p. 28], and Hazlitt [1964/94]. The following analysis will therefore not only attempt to evaluate how "Europe 2020" deals with the knowledge and incentive problems, but will also discuss potential negative impacts of suggested policy measures on the societal order.

\section{Goals and Instruments of "Europe 2020"}

"Europe 2020" has been adopted against the background of persistent economic problems of the European Union. As figure 1 shows, the EU's growth was already disappointing before the global financial crisis of 2007 as well as the euro and debt crises of 2009. This is reflected in the low annual GDP growth rates which, since the mid-1990s, have usually lagged behind not only those of the United States but also of several emerging markets, including the BRIC countries.

The low growth rates are related to low levels of investment (Figure 2) and innovation. As a result, productivity developments have remained weak. Since 2000, total labour productivity per worker grew annually by a mere $0.8 \%$ in the EU, compared to $1.2 \%$ in the OECD on average [OECD, 2014, p. 20]. Not surprisingly, unemployment continued to grow and set new records (Figure 3) as unemployment rates reached double-digits in several member states, and were often twice as high for young people. 
FIGURE 1. Annual rate of growth (in \%) in real GDP for the EU (28), USA, Germany, China and Russia, 1997-2014

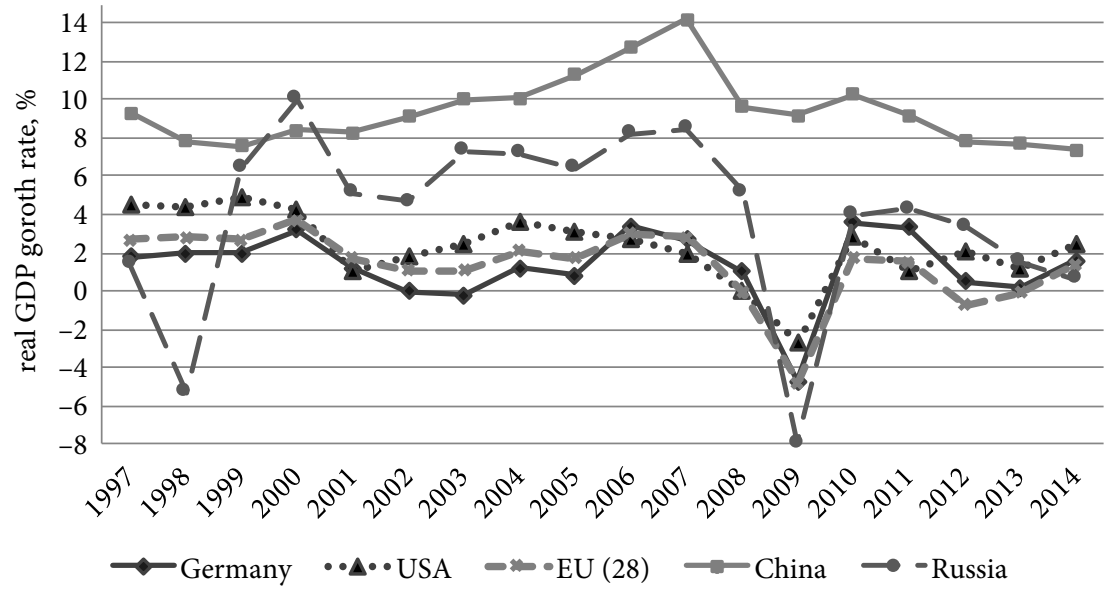

S o u r c e: Eurostat and OECD statistics.

FIGURE 2. Gross fixed capital investment in the EU, Germany, USA and Japan, 2000-2014 (annual growth in \%)

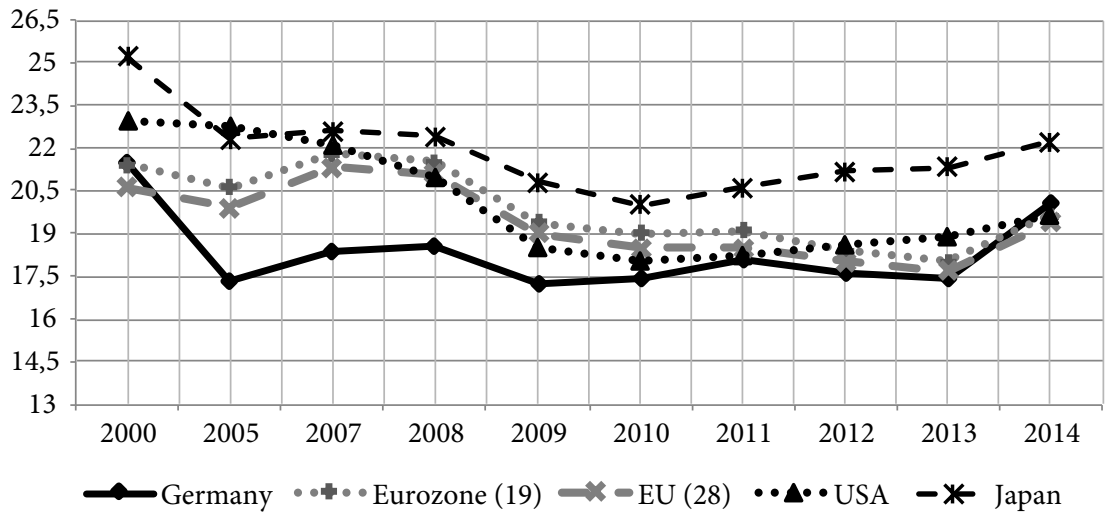

S o u r c e: Eurostat, OECD \& World Bank statistics.

This is in contrast to developments in the United States and the two largest BRIC countries - Russia and China. In the USA, the initial impact of the recession on employment following the financial crisis was much worse, but job creation then resumed and the unemployment rate declined from its post-2007 heights. 
FIGURE 3. Unemployment rates in the EU, Germany, USA, China and Russia, 1998-2014 (as a percentage of labor force)

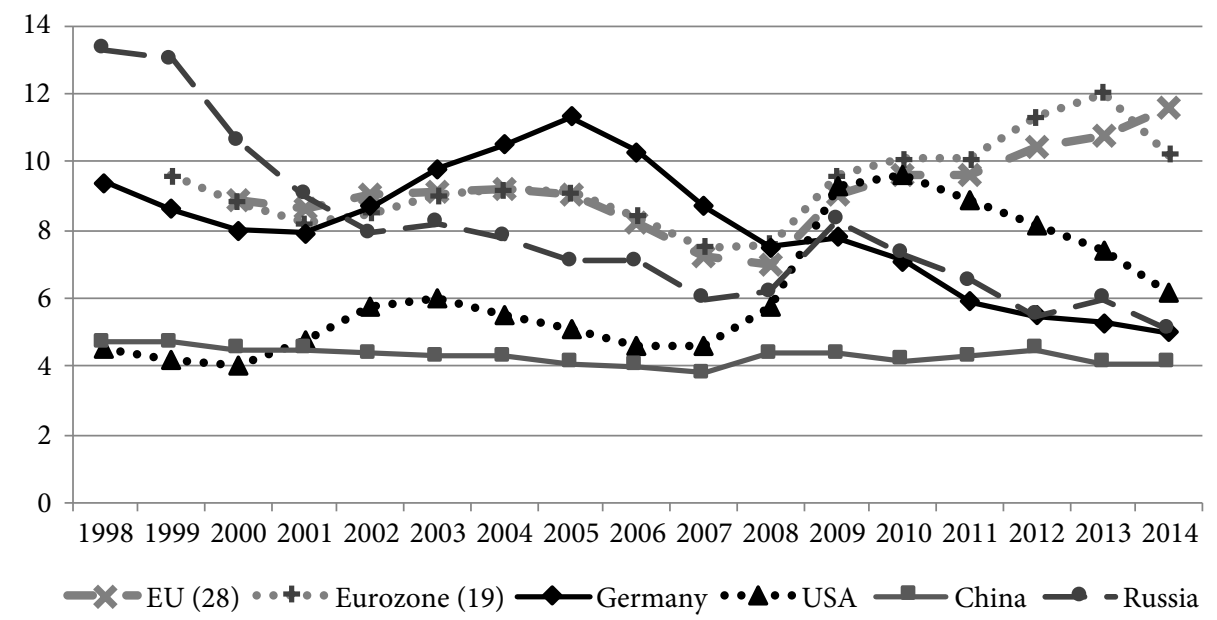

S o u r c e : Eurostat, OECD \& World Bank statistics.

The EU's "Europe 2020" strategy aims at tackling these economic challenges after the Lisbon Strategy of 2000 failed to make Europe the most dynamic region in the world. ${ }^{2}$ The current agenda calls for three mutually reinforcing priorities: "developing an economy based on knowledge and innovation, promoting a more resource efficient, greener and more competitive economy; and fostering a high-employment economy delivering social and territorial cohesion" [European Commission, 2010, p. 3]. These three priorities are also expected to form the pillars of a European social market economy model for the 21 th century.

Like the Lisbon Strategy, "Europe 2020" seeks to reconcile economic growth with social justice, social cohesion and environmental concerns. In fact, the new strategy lays even greater emphasis on these issues as evidenced by the attributes sustainable, inclusive and smart in the agenda's subtitle. Thus, instead of quantitative growth the EU obviously has shifted its priorities towards qualitative growth.

The major policy measures proposed to achieve the key targets and priorities of "Europe 2020 " are laid down in seven so-called flagship initiatives. Their analysis allows reveals the role attributed to governments and markets in promoting growth and the nature of the market economy envisioned in "Europe 2020". Particularly insightful are the flagships: "innovation union"; "industrial policy"; and "resource efficient Europe". Table 1 illustrates the major policy measures suggested in these flagships. Strategic planning, steering, and regulating the economic process to achieve certain ends by the EU-Commission and member country governments - as well as collective coordination procedures between the Commission and business associations - are expected to play an important role in "Europe 
2020". Even the policy instruments characterized as "market-based" in the flagship initiative "resource efficient Europe" are, to a large extent, actually typical instruments of investment steering.

\section{TABLE 1. Policy measures of selected flagship initiatives}

\begin{tabular}{|l|l|l|}
\hline \multicolumn{1}{|c|}{ Innovation Union } & \multicolumn{1}{|c|}{ Industrial policy } & \multicolumn{1}{c|}{ Resource efficient Europe } \\
\hline $\begin{array}{l}\text { Develop a strategic research } \\
\text { agenda focused on challenges } \\
\text { such as energy security, transport, } \\
\text { climate change and resource } \\
\text { efficiency, health and ageing, } \\
\text { environmentally-friendly } \\
\text { production methods and land } \\
\text { management }\end{array}$ & $\begin{array}{l}\text { Close cooperation between the } \\
\text { Commission with stakeholders } \\
\text { in different sectors (business, } \\
\text { trade unions, academics, NGOs, } \\
\text { consumer organisations) to draw } \\
\text { up a framework for a modern } \\
\text { industrial policy }\end{array}$ & $\begin{array}{l}\text { To mobilise EU financial } \\
\text { instruments (e.g. rural } \\
\text { development, structural funds, } \\
\text { R\&D frame-work programme, } \\
\text { TENs, EIB) }\end{array}$ \\
\hline $\begin{array}{l}\text { Enhance joint programming with } \\
\text { Member States and regions }\end{array}$ & $\begin{array}{l}\text { To guide and help industry } \\
\text { to meet these challenges } \\
\text { to promote the competitiveness of } \\
\text { Europe's primary, manufacturing } \\
\text { and service industries }\end{array}$ & $\begin{array}{l}\text { Market-based instruments (e.g. } \\
\text { omissions trading, revision } \\
\text { framework, encouraging wider } \\
\text { use of green public procurement) }\end{array}$ \\
\hline $\begin{array}{l}\text { Make full use of demand side } \\
\text { policies, e.g. through public } \\
\text { procurement and smart regulation }\end{array}$ & $\begin{array}{l}\text { To help industry seize } \\
\text { opportunities of globalisation and } \\
\text { of the green economy }\end{array}$ & $\begin{array}{l}\text { To accelerate the implementation } \\
\text { of strategic projects with high } \\
\text { European added value to address } \\
\text { critical bottlenecks }\end{array}$ \\
\hline $\begin{array}{l}\text { To launch 'European Innovation } \\
\text { Partnerships' between the EU and } \\
\text { national levels to speed up the } \\
\text { development and deployment of } \\
\text { the technologies needed to meet } \\
\text { the challenges identified, i.a. } \\
\text { 'building the bio-economy by 2020' }\end{array}$ & $\begin{array}{l}\text { To develop a horizontal approach } \\
\text { to industrial policy combining } \\
\text { different policy instruments (e.g. } \\
\text { "smart" regulation, modernised } \\
\text { public procurement, competition } \\
\text { rules and standard setting), } \\
\text { promote clusters and improve } \\
\text { affordable access to finance }\end{array}$ & $\begin{array}{l}\text { To establish a vision of structural } \\
\text { and technological changes } \\
\text { required to move to a low carbon, } \\
\text { resource efficient and climate } \\
\text { resilient economy by 2050 }\end{array}$ \\
\hline
\end{tabular}

S o urce: European Commission [2010].

This is further reinforced by suggestions made in section 3.2 of "Europe 2020," where it is emphasized that "social and territorial cohesion will remain at the heart of the Europe 2020 strategy" [European Commission, 2010, p. 20] and that cohesion policy and structural, agricultural and rural development funds are key instruments for reaching the overall goal of the agenda. In order to improve the effectiveness of these tools the European Commission [2010] calls for the development of "innovative financing solutions" fostering investment, e.g. public-private partnerships, better targeting of EU-funds, which are considered to "have an important catalytic effect" as well as a prominent role of the European Investment Bank and the European Investment Fund in kick-starting innovative ventures. 
In addition to these measures where $\mathrm{EU}$ institutions and national governments attempt to direct private entrepreneurs in a desired direction with targeted benefits like financial incentives or smart regulation, the Commission also proposes structural reforms, particularly in labour markets (see the flagship initiative: "An Agenda for new skills and jobs"). Furthermore, it advocates steps to finalize a single market through removing remaining barriers to the free flow of people, goods, services and capital [European Commission, 2010, chapter 3.1] and initiatives to foster trade liberalization both within the WTO and bilaterally (section 3.3).

In order to achieve these goals and overcome the repercussions of the eurozone crisis the Commission suggests strengthening the economic governance mechanism through an open method of coordination with the aim of improving surveillance of national economic policies and their coordination among member states. This includes setting priorities and quantitative targets at the EU-level for all member states ("benchmarking"), an annual monitoring of the economic situation in member countries using a number of indicators to evaluate overall progress towards fulfilling given targets („peer pressing“), publishing country-specific policy recommendations („,best practices“) and issuing policy warnings if a member state fails to fulfill policy recommendations in the agreed time frame [European Commission, 2010, p. 26]. The governance mechanism sketched in chapter 5 of "Europe 2020" has, to a large extent, retained the character of indicative planning without compelling member states to adopt certain policies with the threat of sanctions if they do not comply with the Commission's policy recommendations [Wagner and Eger, 2014]. Yet, in the so-called "six-pack" legislation, which was passed in December 2011 to counter the European sovereign debt crisis through reinforced economic governance, the possibility to impose sanctions was foreseen. Sanctions in the form of fines and the temporary suspension of payments from EU's structural and cohesion funds ${ }^{3}$ can now be levied on member countries not only within the reformed Stability and Growth Pact, where this possibility was already present in its pre-crisis version, but also in the Macroeconomic Imbalances Procedure and the Treaty on Stability, Coordination and Governance (Fiscal Compact) of 2013. However, the imposition of sanctions can still be blocked if a large majority of governments in the EU Council oppose it [European Commission, 2015].

This relatively centralized approach to economic governance and the economic policy suggestions outlined in the flagship initiatives of "Europe 2020" disclose still a quite dirigiste and technocratic understanding of a market economy, which is characteristic of the French economy [Schüller, 2006, 2011a, 2011b]. "Europe 2020" surely does not propose a very strict form of constructivism where politicians and bureaucrats on the top level of the polity, i.e. on the supranational level of the EU, engage in an all-encompassing vertical planning of individual economic sectors. Instead, in "Europe 2020" politicians and bureaucrats predefine the path of economic and societal development and try to induce private economic actors to fulfill higher-ranked technological, social and ecological goals by offering selective, targeted benefits (e.g. tax reliefs) and by harmonizing national 
regulations. So understood, "Europe 2020" advocates a softer form of interventionism, which Schüller [2006, p. 151] calls selective interventionism. It is kind of a middle way between a free market economic policy and rigid government dirigisme. Nevertheless, it reveals the belief that political actors must and can direct markets in a certain direction and hence align the microeconomic foundation of the economy with political goals.

The Investment Plan for Europe, which was launched by the European Commission on November, 26, 2014 to mobilize over EUR 315 billion of investment over the next three years, supports this view [European Commission, 2014]. Its aim is to overcome the low level of investment in the EU due to "low investor confidence," which in turn is attributed to a lack of sufficient risk-bearing capacity [ibid.]. For this a new public development entity at the European level was established in June 2015; the European Fund for Strategic Investments (EFSI), which performs this risk-bearing or sharing role. The EFSI is endowed with a capital base of EUR 21 billion EU funds and expected to activate private sector funds for so called strategic investments, e.g. transport infrastructure, energy, research and development and for small and medium-sized companies by providing investment guarantees. Projects eligible for support are to be selected by an independent investment committee whose members, are to be appointed by the EU Commission in accordance with the member states. This, however, entails the danger that national interests will drive the selection of projects rather than only economic viability [DB Research, 2014].

The key question is whether a policy concept in which a central authority predefines the path of economic development and aspires to impose tighter surveillances on the member states' economic policies is really robust enough to achieve the goals set by the EU Commission.

\section{The Robustness of "Europe 2020"}

In the following subsections the problems of inadequate knowledge, adverse incentives, and potential political and societal side-effects and backlashes are examined.

\section{Underestimation of the Knowledge Problem}

The economic policy concept outlined in the document of "Europe 2020," and subsequent policy initiatives to weather the eurozone crisis, assume that the knowledge necessary to promote economic and social progress is known primarily to scientists and technocrats and needs to be gathered, evaluated and directed according to a certain plan in order to ensure its most efficient and politically desired use. In addition, as the attempts to strengthen more and more economic surveillance of member states indicate, it reveals the conviction that political mechanisms of control are superior to the disciplinary property of the market process. According to Hayek, this is a "fatal conceit" [1991]. He [1937, 1945] has shown that the capability of human beings to acquire full knowledge of complex 
structures, such as modern economies based on the division of labour is, in fact, very limited. This concerns not only the economic agents acting on markets but also economists and politicians watching an economy. The reason is the limited cognitive abilities of any person to capture and process all relevant information used in making economic decisions. The most important information pertains to what is needed, who needs it, and who has the means to meet these needs.

Since this imperfection is irremediable, Hayek speaks of insuperable or "constitutional" limits to knowledge. In fact, the knowledge needed for economic decision-making is dispersed and fragmented among the many individuals who compose society. It is held separately and locally, and frequently contained in inarticulate forms. Even those who possess this so called tacit knowledge are often unaware of it. Therefore, this knowledge can never be entirely given to anyone. This is the problem of the division of knowledge [Hayek, 1945, p. 528]. Consequently, it is impossible for a centralized body of experts and politicians to have the knowledge required to predefine promising technologies, sectors, markets and business structures as envisaged in "Europe 2020" and target prospective strategic investments as envisioned in the 2014 Investment Plan for Europe. In fact, the distance between decision makers and those with market knowledge is the root cause of the knowledge problem in policymaking. Therefore, centralizing a growing number of strategic economic policy issues on a supranational level makes the knowledge problem more severe.

The essential question for Hayek [ 1937 and 1945] is how society can make use of this dispersed knowledge to ensure economic growth and prosperity. This requires a mechanism that is able to activate and communicate information about which goods and services best meet the needs of the people. According to Hayek [1945] this information can only be generated and transmitted by market competition through profit-and-loss feedbacks and changes in relative prices. These profit-and-loss feedbacks provide the necessary incentive for individuals to constantly acquire new knowledge about consumer needs and the best ways to meet them. If successful they are rewarded by profits; otherwise they suffer losses which force them to correct their errors. This is why Haek [1978] called competition a "discovery procedure."

Of course, in this decentralized trial-and-error process mistakes occur. However, when many different decision-makers are involved in different decisions, in a free market environment the consequence of any particular error is minimized as errors are quickly corrected through either bankruptcy or the takeover of inefficient enterprises. As a result, a process of trial-and-error learning is facilitated that ensures that "more of the potentially useful objective facts will be taken into account than would be done in any other procedure we know" [Hayek, 1990, p. 68]. By contrast, if the search for relevant economic information and strategic decision-making is collective and centralized and the people engaged in it make mistakes, then the consequences are much more far reaching than if the decision-making power is more dispersed. Now many economic agents are being guided 
in the wrong direction by politically set incentives like those proposed in "Europe 2020". In the end, taxpayers usually have to pay for the mistakes of centralized decision-makers [Pennington, 2011b, p. 2f].

The knowledge problem is also underestimated when it comes to finding and implementing an appropriate economic policy design for the EU that is conducive to "smart, sustainable and inclusive" economic growth and resistant to crises. From a robust political economy perspective the need for centralized non-market control and sanction mechanisms for surveillance and coordination of member states' economic policies and performance with ever more sophisticated top-down provisions, as outlined in the European economic governance mechanism in section 3, is highly questionable. Because of irremediable ignorance there is no plausible reason to assume that centralized bodies of specialists are better able to detect and prevent crises and declining competitiveness across all member countries no matter how skilled the experts are and how intensively and frequently they carry out their analyses. In the Hayekian understanding of competition, the market process is a much more efficient discovery and control mechanism also for appropriate policy designs. People and capital would exit EU countries with unfavourable policies for EU countries with better conditions thereby exerting pressure for reforms. Admittedly, the element of sharing best practices in the EU's open method of coordination contains a component of institutional or regulatory competition because member countries are free to apply the policies that they consider appropriate to reach the goals agreed to on the EU level. This points to the possibility of policy experimentation. At the same time, however, the European Commission provides recommendations to the member states about the best practices they should apply and monitors their implementation under the threat of blaming and shaming and sanctions. This reduces the intensity of regulatory competition. Taken to the extreme, harmonization of economic policies might be compelled within the EU economic governance mechanisms if sanctions are threatened. Similarly, institutional competition would be severely hampered if the harmonization of taxes, labor, environmental and technological standards is pursued because this impedes the mobility of the factors of production, which is the most effective sanctioning mechanism for economic policy [see also Berthold, 2014].

The need for increased political control mechanisms and state-provided targeted benefits from $\mathrm{EU}$ institutions and national governments in the attempt to ensure the "right" results is usually justified by market failures. Much of mainstream literature and public opinion blames the failure of "unregulated" financial markets and institutions and irrational exuberance for the financial and euro zone crises, underpinning the call for tighter political oversight over markets. The offer of subsidies and other state-provided benefits for investment is often justified by coordination failures, information and other externalities, which are thought to be responsible for the shortage of private investment in projects considered valuable to society [see e.g. Rodrik, 2014; Greenwald et al., 2014; Wruuck, 2015].There are two objections, empirical and theoretical to these arguments 
from the viewpoint of robust political economy. First, there many studies within the Austrian School of Economics and German ordo-liberalism that show that the root cause of the crises were not various market failures, but instead distortions brought about by various government interventions [see e.g. Bagus 2010; Erlei 2014; Balcerowicz, 2015]. In particular, these interventions ${ }^{4}$ weakened, if not suspended, the accountability of economic actors, an element which Walter Eucken, the most prominent representative of the Freiburg ordo-liberal school of economics, considered central to the functioning of a market economy. Second, the market failure argument only makes sense in the neoclassical theory of the market with perfect competition as the benchmark model. It views competition as an allocation mechanism generating Pareto-optimal outcomes in the form of market equilibrium. However, since real-world markets are never in perfect competitive equilibrium they necessarily "fail" all the time, if compared to this ideal [Carden, Horwitz, 2013]. Yet, in the Austrian understanding the market mechanism does not possess goals and benchmarks against which one can compare its performance [Buchanan, Vanberg, 1991] and therefore markets cannot fail. As previously noted, competition is primarily understood as a discovery procedure. But the precise outcomes of this discovery procedure are unpredictable because of the complexity and openness of the market process in conjunction with the limited cognitive abilities of individuals. Otherwise, competition would be unnecessary [Hayek 1978]. In order to perform its discovery function market competition does not need to be perfect [Hayek, 1990]. On the contrary, as Kirzner [1973] showed, it is precisely these so called "market failures" that offer an unexploited profit opportunity for alert private entrepreneurs.

Kirzner $[1973,1982,1997]$ highlighted that the driving force in the discovery procedure of the market process are private entrepreneurs and not politicians and technocrats. Driven by the prospect of profit and the penalty of loss they try to discover and use gains from trade that were hitherto unknown to market participants. Because they invest their own resources, they are careful when making their investment decisions. In contrast, as Kirzner [1978] explained, government bodies face completely different incentives. They usually do not capture pecuniary profits in the course of their activities and are not subject to the same constraints as private firms. Typically they use taxpayer money and do not face bankruptcy in the case of long-term losses. This encourages risky behaviour and frequent investment in large-scale, visible projects deemed to contribute to economic growth, but that in fact often are not economically viable. Therefore, it is questionable whether public financial and development institutions like the EFSI are able to identify profitable projects, as the EFSI is expected to support investment projects which private investors would not finance because of lack of profits [DB Research, 2014].

Given these insights, from the perspective of robust political economy the unhampered entrepreneurial discovery process of the market is the only way to find out innovative technologies, products, and organizational forms that best serve consumers' preferences and overcome EU's stagnating growth. Seen in this light, large parts of "Europe 2020" can 
be considered as being prone to the "pretence of knowledge" [Hayek, 1989], because this strategy predefines certain market outcomes like, for example, building a bio-economy by 2020 , the use of certain forms of business organization (clusters) or a specific amount of renewable energy resources. Section 3 of "Europe 2020" also suggests policy and governance instruments to push the market process into a direction yielding desired results. Hayek [1990, p. 169] considers such an approach "the extreme of hubris" and points out that such guided progress would in fact be no progress at all. ${ }^{5}$

The constitutional ignorance of human beings, in combination with the complexity and openness of market processes, make it unlikely that politicians will have superior knowledge of profitable innovations as compared to private entrepreneurs. It can also not be expected that they will have the knowledge needed to precisely steer economic activities in a desired direction. Instead, there will often be unintended and unexpected side-effects. As Ludwig von Mises [1976/96] demonstrated, politicians usually do not abandon wrong policy measures, because "either governments don't want to lose face, or, more commonly, politically powerful interest groups impede the ability of governments to abandon their interventions" [Baumol et al., 2007, p. 70]. Instead, policy-makers will try to correct unwanted side-effects with further interventions, setting in motion a destructive spiral of more government controls. ${ }^{6}$ Numerous empirical evidence from the EU supports this insight, e.g. EU's Common Agricultural Policy, the support for Airbus (e.g. A 380) or Germany's capital airport in Berlin und renewable energy policy.

The logical consequence should therefore be abstention from government-intervention into the market process to attain certain outcomes, no matter how "soft" or "smart" they look. Instead the EU's economic policy should focus exclusively on supporting institutions that enhance competition and productive entrepreneurship. A growing body of empirical literature underscores the central importance of the right institutional set-up for economic growth and prosperity [e.g. Douglass North, 1990; Mancur, Olson, 2000; Hernando de Soto, 2000; Acemoglu, Robinson, 2012]. Crucial institutions are: freedom to action and contract; free market entry; well-defined and protected property rights; a simple, non-confiscatory tax system; and, given the experience of the global financial and European sovereign debt crises, the rigorous and impartial enforcement of accountability. Against the background of these insights the call for structural reforms and deepening the single market in "Europe 2020" goes in the right direction and is in line with robust political economy, because it improves the discovery properties of market competition. However, as shown in section 3 this is only one part of the current ten year strategy. Political control and coordination, rather than the knowledge-generating, coordinating and disciplining power of the unhampered market mechanism, are still central elements of this strategy and seem to have gained importance and popularity in the wake of the eurozone crisis as indicated by calls for "more Europe" and "economic government." [Wohlgemuth, 2012; Berthold, 2014]. The report of the presidents of the EU's five central institutions ${ }^{7}$, "Completing Europe's Economic and Monetary Union" of June 22, 2015 [Juncker et al., 
2015], points to this same direction. It restates the conviction that the EMU needs more centralization of competences at the European level and calls for the creation of Competitiveness Authorities and the stipulation of more binding "high-level standards that would be defined in EU legislation" (for a more detailed discussion see Issing [2015]).

In the view of robust political economy, this aspect of the EU's current economic policy not only underestimates knowledge requirements, but is also susceptible to big incentive problems in suggested economic policy measures to promote smart, sustainable and inclusive growth and in configuring the EU's economic governance mechanism.

\section{Promotion of Rent-Seeking}

As Baumol et al. [2007] described, any form of state-guided economic development leads to a non-transparent enmeshment of political and economic interests that promotes rent-seeking and corruption. The more the government intervenes and allures with subsidies or other selective benefits, the more people will be induced to divert investment from better serving consumer needs to influencing politicians to obtain and maintain these targeted benefits [Buchanan, 1987].

Targeted government benefits are esteemed by enterprises because they provide advantages over rival firms that are not selected to obtain them. Therefore, companies will undertake considerable efforts to signal to policy-makers that they are a worthy recipient. They will also lobby for more rent opportunities, which may lead to "regulatory capture" [Laffont, Tirole 1991], i.e. to situations where interest groups have become influential in shaping government policies. Regulatory capture is a much more advanced form of rent-seeking and requires considerable resources to influence government policy, for example for the elaboration of adequate policy suggestions and mobilization of political support. As a result, productive entrepreneurial activities are superseded by unproductive or even destructive activities [Baumol, 1990]. Conversely, self-interested policy-makers have an incentive to engage in rent-provision to secure re-election and retain power. This can easily lead to a self-enforcing process, as government favours can quickly turn into vested rights. Any attempt to abolish these favours may cost the political support of the favoured group, while the simple preservation of existing regulation does not necessarily guarantee future support [Coyne and Moberg, 2014, p. 22f].

Usually the introduction and maintenance of regulations that ease rent-seeking is justified under the rubric of public-policy goals, in particular with the blank terms "social justice" and "sustainability", i.e. environmental protection. Both of these aspects play a key role in the strategy "Europe 2020" (see section 3), and enable policy makers and interest groups to constantly introduce new interventions to redistribute wealth, which further undermines the productive power of the market order. That is why Hayek [1979/2004] called the byword "social" in the term social market economy a weasel word, i.e. a word that deprives terms of their actual meaning when they are added to them. The same can be said of the other popular adjectives "ecological" and "sustainable." Nobody knows what 
they actually mean. This led Hayek [1979/2004] to conclude that a social market economy is in fact no market-economy. In a similar vein, Mancur Olson [1982] has shown that if economic life becomes increasingly controlled by rent-seeking organized interest groups under the disguise of social or other alleged public concerns, it loses economic dynamism. Consequently, economic performance declines, because the policies are typically protectionist and stifle economic growth. Olson called this situation institutional sclerosis. Herbert Giersch in the 1970 s applied this term to the EU's economic stagnation at that time and coined the term "eurosclerosis." This does not mean that EU policy-making in the current context of "Europe 2020" and the European sovereign debt crisis is unaware of the stifling effects of regulated markets. The call for structural reforms and the plea to finalize the single market by removing the remaining barriers to the free flow of factors of production, goods and services indicates this. Nevertheless, the importance attributed to social and ecological goals in the EU's economic policy strategy maintains its susceptibility to these incentive problems with its negative repercussions on economic growth. Therefore, from the robust political economy perspective, the most effective way to minimize this danger is to provide as few opportunities as possible to obtain income transfers.

\section{Missing Credible Incentives for Structural Reform}

An additional incentive problem arises from the EU's reinforced economic governance mechanism, which is based on the questionable belief that without a stronger surveillance of EU member states by EU institutions, sluggish growth cannot be overcome and future crises cannot be prevented. Even if there was a convincing rationale for this normative conclusion, such a mechanism lacks credible and effective incentives for national governments to implement policies conducive to these goals, because the power of EU institutions to force member states to undertake certain behaviors is very limited. First, the sanctions foreseen in the Stability and Growth Pact, the Macroeconomic Imbalances Procedure and Fiscal Compact in the form of fines and suspensions from EU transfer payments are relatively weak and might not be perceived as sufficiently painful by non-complying countries to compel them to make desired changes. Second, EU institutions lack tools to enforce sanctions, other than to hold back transfer payments. There is nothing they can do to prevent actual "sinners" from refusing to pay. This is even more so as the sanction cannot be imposed against the consent of the member countries. The emasculation of the Stability and Growth Pact by Germany and France in 2005 demonstrated that potential sinners are usually reluctant to sanction actual sinners. Moreover, the commitment to solidarity among member countries, expressed in "Europe 2020" and through the existence of the cohesion fund, the non-enforcement of the no-bail-out clause and the stated will to avoid dissolution of the European Monetary Union add to this reluctance. But even if there were the means to enforce sanctions this would be politically very risky, because, as discussed in the next sections, it would endanger the peaceful cooperation of the European countries. As long as there is no credible threat of far-reaching sanctions, 
the costs of poor national economic policies can be socialized and, in effect, outsourced to be borne by other European states. In such a situation, there is little reason to expect that national governments will apply politically unattractive economic policies that are imposed on them from outside. Hence, there is no convincing reason to believe that more centralized political control is more efficient in keeping the behavior of member states in line and accountable for their actions than market process [see also Wohlgemuth, 2012, Apolte, 2015; Issing 2015].

\section{Potential Societal Backlashes}

Interventionist economic policies not only inhibit economic growth through the described insurmountable epistemic constraints and perverse political incentives, but may also in the long run have negative effects on the societal order because they can lead to a transformation of society through the growing diminution of personal liberty and self-determination. The reasons why this may occur not only in totalitarian systems, but also in western democratic welfare states (which most of EU's member states are) were laid down by Hayek in 1944 in his book "The Road to Serfdom". It shall be noted that these arguments, which we will apply to EU's current growth strategy, do not assert an iron-clad inevitability of the future development of the European society. Instead, they point to other often overlooked side-effects of government interference in the economy and explain why despite - good intentions - the popular belief that regulated markets for social, ecological or other reasons completely go together with individual freedom, democracy and an impartial rule of law is a fallacy [see also Boettke, 2014].

The starting point for the threat to individual freedom in modern societies through interventionist policies is the desire for economic security, which is understood as the guarantee of a certain level of standard of living as well as recent requests for ecological security (environmental protection). Hayek [1944/2006, p. 157] shows that such security, as well as any other higher-ranked societal goals, are only attainable through the regulation and, ultimately, the elimination of the market. There are numerous examples of such regulations in the EU, the most prominent being the ban of incandescent and halogen light bulbs or powerful vacuum cleaners with motors above 1,600 watts for energy efficiency reasons in the attempt to tackle climate change [FAZ, 27.08.2014].

The suppression of the free market mechanism, in turn, continuously diminishes and liquidates individual liberty, because when more prohibitions and commands regulate economic life they simultaneously reduce the scope for general individual freedom. As Hayek [1944/2006, p. 95] explained, this is because "economic control is not merely control of a sector of human life which can be separated from the rest; it is the control of the means for all our ends. And whoever has sole control of the means must also determine which ends are to be served, which values are to be rated higher and which lower, in short, what men should believe and strive for". Hence, the demand to steer economic development for everyone into a certain direction for the sake of social or environmental goals 
requires the concentration of power of a magnitude never before known in the hands of a central authority over individuals [Hayek, 1944/2006, p. 185]. If, according to Hayek, this road is followed it may eventually lead (however unintentionally) to a socialist-totalitarian society deprived of individual liberty, prosperity, and peaceful national and international cooperation.

Conversely, in a competitive society, there is "nobody who can exercise even a fraction of the power which a socialist planning board would possess" [Hayek, 1944/2006, p. 149]. Since the decentralization of power means reducing the absolute amount of power "the competitive system is the only system designed to minimise the power exercised by man over man" [ibid.]. In this context, "the separation of economic and political aims is an essential guarantee of individual freedom' and "the substitution of political for economic power" means replacing power from which there is no escape with power which is always limited. So called economic power, which can be an instrument of coercion, is in the hands of individuals never exclusive or complete power over the whole life of a person. But centralised as an instrument of political power it creates a degree of dependence scarcely distinguishable from slavery" [Hayek, 1944/2006, p. 150].

Also from an ethical and moral point of view it is doubtful that the direction of economic process according to higher-ranked, "ideal" objectives as expressed in the adjectives "inclusive" and "sustainable" in "Europe 2020" raises society's moral standards. Rather the opposite is the case. With regard to government prescribed or provided poverty relief measures or top-down enforced ecological programs to compel citizens to what is held environmental friendly behaviour, Hayek [1944/2006, p. 216f] has pointed out "only where we ourselves are responsible for our own interests and are free to sacrifice them, has our decision moral value. We are neither entitled to be unselfish at someone else's expense, nor is there any merit in being unselfish if we have no choice. The members of a society who in all respects are made to do the good thing have no title to praise." And he [p. 218] continues: "A movement whose main promise is the relief from responsibility cannot but be anti-moral in its effect however lofty the ideals to which it owes its birth". There is a big the difference "between demanding that a desirable state of affairs should be brought about by the authorities or even being willing to submit provided everyone else is made to do the same, and the readiness to do what one thinks right oneself at the sacrifice of one's own desires and perhaps in the face of hostile public opinion " [ibid.]. As Erlei [2014], with regard to Germany, demonstrates there is in fact much evidence for the first tendency in at least some European societies. In Germany national economic policy focuses increasingly on redistribution rather than on providing an institutional environment conducive to creating wealth.

Hayek [1944/2006, p. 227ff] further shows that the societal and ethical problems are caused by the conscious direction of economic affairs on a national level "inevitably assume even greater dimensions when the same is attempted internationally", for example on the EU level. "The conflict between planning and freedom cannot but become more 
serious as the similarity of standards and values among those submitted to a unitary plan diminishes". The reason for this is that the amount of agreement on the order of ends decreases as the scale of a community increases, so that the necessity to rely on force and compulsion grows. ${ }^{8}$ Hayek [1944/2006, p. 229] concludes: "Planning on an international scale, even more than is true on a national scale, cannot be anything but a naked rule of force, an imposition by a small group on all the rest of that sort of standard and employment which the planners think suitable for the rest". As a result a tendency towards growing centralized control over national policies and certain markets in a community like the EU with widely divergent traditions, ideals and levels of economic development can threaten its cohesion and integrity and become what Röpke [1959] called dynamite and an instrument of disintegration. Hence, in addition to the knowledge and incentive issues this threat is a further reason why the preference expressed in the EU's economic governance mechanism towards more centralized control is not an appropriate way to achieve a sustainable future for the EU. Instead, reinforcement of the principle of subsidiarity is more likely to ensure a democratic and free European society and the public's support for it [Issing, 2015].

Otherwise, as Hayek [1944/2006, p. 231] argued "it is fairly certain that in a planned international system the wealthier and therefore most powerful nations would to a very much greater degree than in a free economy become the object of hatred and envy of the poorer ones: and the latter, rightly or wrongly, would all be convinced that their position could be improved much more quickly if they were only free to do what they wished." Such signs have in fact become visible in the EU in the wake of the European sovereign debt crisis and the rescue measures undertaken to remedy it. In particular, Germany with its insistence on austerity, structural reforms and adherence to rules is perceived as an oppressive power, disciplining hegemon or an egotistical economic occupier in the countries affected by the eurozone crisis, with Greece being the most prominent example ${ }^{9}$ [Spiegel Online, 23.03.2015]. A further indication is the rising support for euroskeptic, anti-establishment and populist parties of both the right and the left in a number of European countries like France, Spain, the United Kingdom, Greece or Hungary [Economist, 31.05.2014]. As Mayer [2016] pointed out, irrespective of the political spectrum in which they are located the economic policy concept of most of these parties is similar in its anti-free market and trade and highly interventionist orientation. As such they are largely ignorant of knowledge constraints, the incentive problem and the societal side-effects. Therefore, they do not offer a robust economic policy alternative.

\section{Implications for the Member States}

Irrespective of these flaws, with regard to robustness of the economic policy of "Europe 2020" and subsequent economic policy arrangements and initiatives it is far from certain that a uniform European economic policy and unified model of a social market economy can be implemented throughout the European Union. This would require two 
preconditions: first, compliance with the preferences member state populations, and second, the concentration of power on the supranational level and credible commitment to exercise impartial control on member countries' economic development.

Rooted in the school of economic ordo-liberalism, Germany is traditionally considered an advocate of more market-oriented economic policies, alongside the United Kingdom (UK), while France usually stands for a centralized and dirigiste approach. Meanwhile there is some evidence that the preferences for economic policies in Germany have shifted towards the French attitude, while Great Britain is still an adherent to a decentralized and much more market-driven economic policy for the EU. Indications of this dismissive attitude towards "more Europe" include the speech of the British Prime Minister, David Cameron, in January 2013 on the UK's relation with the EU, the planned referendum on the UK's EU membership, and Cameron's resistance to the appointment of the new president of the EU Commission in May 2014.

Conversely, Germany seems to have gradually given up the legacy of the father of its social market economy, Ludwig Erhard, who unequivocally stood for a market-oriented economic policy both on the national and European level. For Erhard the social market economy was always first and foremost a market economic system [Goldschmidt, 2004, p. 12]. He was convinced that "the freer an economy is, the more social it is" [Erhard, 1966, p. 320]. Since Erhard left politics, this view has been abandoned throughout the post-war period until present. In particular, since the Maastricht Treaty of 1992 and under the government of Gerhard Schröder (1998-2005) Germany adopted more French ideas of economic policy with a preference for supranational collective actions and the "primacy of politics" [Schüller, 2011b]. Under Chancellor Angela Merkel this course has been continued. Major decisions of the latest German federal government formed by the grand coalition of Christian Democrats (CDU/CSU) and Social Democrats (SPD) in 2013 are even further unswerving steps towards more interventionism. Examples are the introduction of minimum wages and price ceilings on the rental market as well as the continuation of a centrally-planned energy transition policy.

This is in stark contrast to what Germany demands from the member countries affected by the eurozone crisis. While it vigorously insists on profound market-oriented structural reforms in exchange for financial support, on the national level the German government intervenes into markets by setting certain desirable market outcomes. At the same time on the European level it advocates tax harmonization, its centrally-planned renewable energy policy, and supports France's idea of a European economic government. However, left open is precisely what this economic government is meant to do. In Jamet et al. [2011] Mussler argues that in the German understanding such an economic government should focus primarily on a rule-based economic coordination and surveillance of competitiveness. This means tightening the stability pact and other existing rules and ensuring their impartial automatic enforcement. It remains to be seen whether this different emphasis is really substantial or only semantic. 
Apparently, the soft interventionist approach of "Europe 2020" as well as the interventionist policy measures of Germany's grand coalition government meet the preferences of large parts of the German population and seem to be in line with the "public" opinion pronounced by the media. Both increasingly blame unhampered market forces for all existing economic problems, instead of excessive government interventionism. The results of a survey carried out by the Allenbach Institute underscore this change in attitudes towards a market economy. More Germans favour stronger government intervention, and some even desire the introduction of a planned economy (Deutsche Wirtschafts Nachrichten, 28.11.2013). This attitude has gained popular support since the outbreak of the global financial and eurozone crisis.

Nevertheless, the experiment with the introduction of a common currency for countries with relatively heterogeneous economic development levels has demonstrated that a one-size-fits-all-economic policy is not feasible, can lead to economic and social upheavals as well as political deformations and would require a further concentration of power in a centralized EU economic government. Yet, at present, the member states are reluctant to delegate power to Brussels that allow far-reaching interventions into their national economies. Most prominently, the United Kingdom demands the decentralization of decision-making, and otherwise threatens a Brexit. But even if there was consensus on a European economic government with far-reaching competences, this would require a credible self-commitment by the member countries to implement policy prescriptions from Brussels, as well as a credible commitment of the EU Commission and the European Council to effectively impose sanctions on member countries who fail in their commitments. Given the many violations of treaties, rules and commitments there is so far no reason to believe that this credibility exits (see also [Issing, 2015]).

As discussed above, from the perspective of robust political economy there is no rationale to implement a unified economic model from above through a centralized governance mechanism. Instead, the only robust and economically and politically efficient mode to foster convergence is to make use of institutional competition where local policy makers offer citizens institutional arrangements and public services conducive to growth and employment and meet the preference of the population. In order to function, institutional competition requires the ability to relocate and, most importantly, that the subnational federal or supranational entity remain accountable for their policies, i.e. that they have no option to externalize the cost of bad policies onto others. In fact the only binding agreement needed is the commitment to not bail out lower level jurisdictions. For even if at this level the free flow of goods and resources was restricted, competition could nevertheless exert its disciplining power on local policy-makers, as people could still voice their dissatisfaction with a deteriorating economic situation. As in the business world the outcome of the discovery process of institutional competition is not predictable. Based on studies of the federal system of Switzerland it is far from certain that this may lead to a "race to the bottom" or a full convergence of policies and institutional arrangements 
across political jurisdictions (see e.g. [Wohlgemuth,Adamovich, 1999; Bessard, 2013]). As Hirschman [1970] argued "loyalty" can be a strong countervailing factor to "exit" and "voice" that creates inhibition thresholds for business to relocate. As a result a high degree of diversity can be preserved with a federal state or supranational polity.

\section{Conclusions}

Like its predecessor, the Lisbon-Strategy, "Europe 2020" suggests a model of a targeted interventionism and administrative coordination and control of economic processes in the Union. Although the importance of structural reforms is acknowledged, these features demonstrate a firm trust in the capability of policy-makers to steer economies into a desired direction and at the same time a great distrust towards the self-coordinative and self-healing powers of unhampered free markets. Thus, "Europe 2020" obviously meets the reservations of large parts of the population towards free markets and their preference for state intervention, not the least of which being its economically largest and powerful member - Germany. However, such a policy approach lacks robustness as it overlooks, or at least underestimates, the crucial pitfalls of any form of interventionism - as shown by the robust economic policy analysis in this paper: the knowledge and incentive problem as well as the impact on the societal order through the diminution of individual liberties. The less economic policy supports the market mechanism understood as an entrepreneurial discovery process, the more unlikely that "Europe 2020" will lead the European Union out of its economic stagnation, because such an institutional environment fosters unproductive rent-seeking rather than productive, wealth enhancing entrepreneurship. As Mises [1976/1996, p. 26] argued there is actually "no middle of the road" between a free market system and an economic system with full government control. Even a light form of interventionism faces the problem of how to deal with its unintended consequences, either to undo the interference or to undertake additional interventions. In the end, such a system with selected interventions can never provide the stable business environment that is crucial for long-term sustainable economic growth.

As early as the $1950 \mathrm{~s}$, German economists pointed to the economic, political and societal flaws of centralized and interventionist strategies of European integration. Ludwig Erhard [1959] warned: "The will to organize and harmonize must inevitably end in the precipice". Instead, he argued that the best way to advance European integration is not the creation of more and more commissions, administrative bodies and bureaucracies, but the restoration and maintenance of an international order that allows economic mobility [Erhard, 1957]. Therefore, the EU's current quest for sustained economic growth ignores his policy conclusion from 1962 that: "We do not need a planning program for Europe, but a program for building a market friendly and competition enhancing institutional 
environment" [Erhard, 1962/1988, p. 770]. As Hayek [1944/2006, p. 234] concluded, in this process "an international authority can be very just and contribute enormously to economic prosperity if it merely keeps order and creates conditions in which the people can develop their own life." This requires the extension of freedoms for private economic actors and member states rather than restrictions through ever new mandatory targets and controlling agencies. In fact, in the past EU institutions have successfully fostered economic freedom and liberalization across Europe through the establishment of a single market [Wohlgemuth, 2007]. From a robust political economy perspective, Europe will only be able to successfully mitigate the knowledge and incentive problems and avoid unintended backlashes on personal liberties if it recalls this liberal tradition and concentrates on providing an institutional environment conducive to unfold the productive power of competition as an entrepreneurial discovery process to the fullest extent possible. Then the EU will indeed have good prospects to become one of the most competitive and prosperous regions with a high quality of life.

\section{Notes}

$1 \quad$ Author's e-mail address: jwandel@gmx.de; jwande@sgh.waw.pl

2 Already in March 2000 the special European Council in Lisbon adopted the so-called the Lisbon Strategy with the broad objective of turning the EU into "the most dynamic and competitive knowledge economy in the world capable of sustainable economic growth with more and better jobs and greater social cohesion and respect for the environment" [Kok et al., 2004, p. 6]. This rather abstract objective of enhanced competitiveness was translated into specific quantitative targets. Among these were an annual GDP growth rate of $3 \%$, full employment by 2010 , and gross domestic R\&D expenditure of $3 \%$. However, by 2004 it had became clear that the objective of turning the EU into the most competitive economy by 2010 was far out of reach. While in the USA, GDP had grown annually by $2.7 \%$ since 2000 , EU's GDP only increased by $1.7 \%$ p.a. [Euractiv, 25.11.2009].

3 In the Stability and Growth Pact fines can be up to $0.2 \%-0.5 \%$ of GDP, and in the Fiscal Compact $0.1 \%$ of GDP. In the Macroeconomic Imbalance Procedure sanctions initially are in the form of interest-bearing deposist that can be then converted into fines (up to $0.1 \%$ of GDP) upon a member country's second failure to comply [European Commission, 2013].

4 These interventions were inter alia perverse credit weights in the Basle capital accords that encouraged domestic banks to lend to governments, tax regulations that favored debt relative to equity financing; subsidized mortgages that encouraged excessive borrowing; federal deposit insurance that eliminated market discipline, monetary and bailout policies [Balcerowicz, 2015].

5 In “The Road to Serfdom” Hayek [1944/2006, p. 169] argues: “To 'plan' or 'organise' the growth of mind, or, for that matter, progress in general, is a contradiction in terms. The idea that the human mind ought 'consciously' to control its own development confuses individual reason, which alone can 'consciously control' anything, with the interpersonal process to which its growth is due. By attempting to control it we 
are merely setting bounds to its development and must sooner or later produce a stagnation of thought and a decline of reason".

6 "The fact that the system functions poorly is blamed exclusively on the law that does not go far enough, and on corruption that prevents its application. The very failure of interventionism reinforces the layman's conviction that private property must be controlled severely. The corruption of 'the regulatory bodies does not shake his blind confidence in the infallibility and perfection of the state; it merely fills him with moral aversion to entrepreneurs and capitalists" [Mises, 1976/96, p. 30].

7 The five presidents are: Jean-Claude Juncker (EU Commission), Donald Tusk (European Council), Jeroen Dijsselbloem (Eurogroup and Board of Governors of the European Stability Mechanism ESM), Mario Draghi (European Central Bank) and Martin Schulz (European Parliament).

8 As Hayek explains: "In a small community common views on the relative importance of the main tasks, agreed standards of value, will exist on a great many subjects. But their number will become less and less the wider we throw the net: and as there is less community of views, the necessity to rely on force and coercion increases" [1944/2006, p. 228].

9 For example the British newspaper "The Guardian" of January 28, 2015 called Angela Merkel "the most monstrous Western European leader of this generation" and compared her to Charlie Chaplin's The Great Dictator.

\section{References}

Acemoglu, D., Robinson, J. (2012), Why Nations Fail: The Origins of Power, Prosperity, and Poverty, New York: Crown Business.

Apolte, T. (2015), Die griechische Tragödie: Warum sich niemand zu handeln traut. Wirtschaftliche Freiheit, available at: http://wirtschaftlichefreiheit.de/wordpress/?p=17284\&print=1, accessed: May 3, 2015.

Bagus, P. (2010), The Tragedy of the Euro, Ludwig von Mises Institute, Auburn, Ala, available at: https://mises. org/library/tragedy-euro.

Balcerowicz, L. (2015), Euro Imbalances and Adjustment: A Comparative Analysis, Cato Journal, Vol. 34, No. 3 , pp. 453-484.

Baumol, W.J. (1990), Entrepreneurship: Productive, Unproductive, and Destructive, The Journal of Political Economy, Vol. 98, No. 5, pp. 893-921.

Baumol, W.J., Litan, R.E., Schramm, C.J. (2007), Good capitalism, bad capitalism, and the economics of growth and prosperity, Yale Univ. Press, New Haven, Conn.

Berthold, N. (2014), The Future of the European Union: Competition or Centralization? Europe has gone too far. Wirtschaftliche Freiheit, available at: http://wirtschaftlichefreiheit.de/wordpress/?p=14732\&amp;print=1, accessed: April 14, 2014.

Bessard, P. (2013), Switzerland's Reformed Fiscal Equalization System, in: J. Clemens, N. Veldhuis (eds.), Federalism and Fiscal Transfers: Essays on Australia, Germany, Switzerland, and the United States, Fraser Institut, Vancouver. B.C. pp. 43-53, available at: https://www.fraserinstitute.org/sites/default/files/federalism-and-fiscal-transfers-rev.pdf Boettke, P.J. (2014), The Road to Serfdom Revisited, George Mason University Department of Economics Working Paper, No. 14-48, available at: http://papers.ssrn.com/sol $3 /$ papers.cfm?abstract_id=2527471

Boettke, P.J., Coyne, C.J. (2009), Context Matters: Institutions and Entrepreneurship, Foundations and Trends in Entrepreneurship, Vol. 5, No. 3, pp. 135-209.

Boettke, P.J., Leeson, P.T. (2004), Liberalism, Socialism, and Robust Political Economy, Journal of Markets \& Morality, Vol. 7, No. 1, pp. 99-111.

Boettke, P.J., Fink, A. (2011), Institutions first, Journal of Institutional Economics, Vol. 7, No. 4, pp. 499-504. 
Buchanan, J. (1987), The Constitution of Economic Policy, The American Economic Review, Vol. 77, No. 3, pp. 243-250.

Buchanan, J.M., Vanberg, V. (1991), The market as a creative process, The Collected Works of James M. Buchanan, 2001, Vol. 18, Liberty Fund, Indianapolis, IN., available at: http://www.libertarianismo.org/livros/vvtcom.pdf

Buchanan, J., Tollison, R.D., Tullock, G. (eds., 1980), Toward a Theory of the Rent-Seeking Society. J.M. College Station: Texas A\&M University Press.

Carden, A., Horwitz, S. (2013), Is Market Failure a Sufficient Condition for Government Intervention?, Library of Economics and Liberty, available at: http://www.econlib.org/library/Columns/y2013/CardenHorwitzmarkets.html Coyne, C.J., Moberg, L. (2015), The Political Economy of State-Provided Targeted Benefits, Review of Austrian Economics, Vol. 28, pp. 337-356.

De Soto, H. (2000), The Mystery of Capital: Why Capitalism Triumphs in the West and Fails Everywhere Else, New York, Random House.

Deutsche Bank - DB Research (2014), Investitionen im Euroraum: Initiativen, Handlungsfelder, Erfolgsfaktoren. EU-Monitor, 18. Dezember 2014, available at:https://www.dbresearch.de/PROD/DBR_INTERNET_ DE-PROD/PROD0000000000348027/Investitionen_im_Euroraum\%3A_Initiativen,_Handlungsf.PDF

Deutsche Wirtschafts Nachrichten, (28.11.2013): Mehr Staat: Deutsche rufen nach Einführung der Planwirtschaft, available at: http://deutsche-wirtschafts-nachrichten.de/2013/11/28/mehr-staat-deutsche-rufen-nach-einfuehrung-der-planwirtschaft/

Economist (31.05.2014), The Eurosceptic Union, available at: http://www.economist.com/news/europe/21603034-impact-rise-anti-establishment-parties-europe-and-abroad-eurosceptic-union

Erhard, L. (1957/1964), Wohlstand für alle, Düsseldorf: Econ-verlag, hier: 8. Auflage, bearbeitet von Wolfram Langer (1964), Ludwig-Erhard-Stiftung e.V., Bonn.

Erhard, L. (1959), Harmonie durch Harmonisierung?, Frankfurter Allgemeinen Zeitung, 31. Dezember 1959, zitiert in: M. Wohlgemuth (2007), Einheit in Vielfalt: Fünfzig Jahre europäische Ordnungspolitik, FAZ, 17.03.2007, p. 11, available at: http://www.eucken.de/fileadmin/bilder/Dokumente/WohlgemuthPolitikreform.pdf

Erhard, L. (1962/1988), Planification - kein Modell für Europa, in K. Hohmann (ed.), Ludwig Erhard. Gedanken aus fünf Jahrzehnten, Düsseldorf, ECON Verlag, pp. 770-780.

Erhard, L. (1966), Wirken und Reden, Ludwigsburg, Verlag Hoch.

Erlei, M. (2014), Die Institutionen der Sozialen Marktwirtschaft erodieren mit steigender Geschwindigkeit, Wirtschaftliche Freiheit, 24. Juni 2014, available at: http://wirtschaftlichefreiheit.de/wordpress/?p=15101

Euractiv (25.11.2009), Growth and jobs: Reshaping the EU's,Lisbon Strategy; available at: http://www.euractiv. com/priorities/growth-jobs-reshaping-eus-lisbon-linksdossier-188511

European Commission (2010), Europe 2020 - A Strategy for Smart, Sustainable and Inclusive Growth, COM (2010) 2020. Brussels, 3 March, 2010, available at: http://ec.europa.eu/eu2020/pdf/COMPLET\%20EN\%20 BARROSO\%20\%20\%20007\%20-\%20Europe\%202020\%20-\%20EN\%20version.pdf

European Commission (2013), Economic and financial affairs - EU economic governance: Six-pack? Twopack? Fiscal compact? A short guide to the new EU fiscal governance, available at: http://ec.europa.eu/economy_finance/articles/governance/2012-03-14_six_pack_en.htm

European Commission (2014), Investment Plan, available at: http://ec.europa.eu/priorities/jobs-growth-investment/plan/index_en.htm\#why

European Commission (2015), Economic and financial affairs - EU economic governance, available at: http:// ec.europa.eu/economy_finance/economic_governance/index_en.htm

Eurostat Statistics, available at: http://epp.eurostat.ec.europa.eu/portal/page/portal/statistics/search_database 
FAZ-Frankfurter Allgemeine Zeitung (27.08.2014), Neue Vorgaben Brüssel will Föhn und Rasenmäher drosseln, available at: http://www.faz.net/aktuell/politik/europaeische-union/vorgaben-bruessel-will-foehn-und-rasenmaeher-drosseln-13118554.html

Goldschmidt, N. (2004), Alfred Müller-Armack and Ludwig Erhard: Social Market Liberalis, Freiburg discussion papers on constitutional economics, No. 04/12, available at: http://www.econstor.eu/bitstream/10419/4344/1/04_12bw. pdf

Greenwald, B., Stiglitz, J.E. (2014), Creating a Learning Society: A New Approach to Growth, Development, and Social Progress, New York, Columbia University Press.

Hayek, F.A. (1937), Economics and Knowledge, Economica, No. 4, pp. 33-54.

Hayek, F.A. (1944/2006), The Road to Serfdom, Routledge, London and New York.

Hayek, F.A. (1945), The Use of Knowledge in Society, The American Economic Review, Vol. 35, No. 4, pp. 519-530.

Hayek, F.A. (1973), Law, Legislation and Liberty, Vol. 1., Rules and Order, University of Chicago Press, Chicago.

Hayek, F.A. (1978), Competition as a Discovery Procedure, in: F.A. Hayek (ed.), New Studies in Philosophy, Politics, and Economics and the History of Ideas, Chicago, University of Chicago Press, pp. 179-90.

Hayek, F.A. (1979/2004),Wissenschaft und Sozialismus, in: F.A. Hayek (ed.), Wissenschaft und Sozialismus. Aufsätze zur Sozialismuskritik, Tübingen, Mohr Siebeck, pp. 52-62.

Hayek, F.A. (1989), The Pretence of Knowledge, American Economic Review, Vol. 79, No. 6, pp. 3-7.

Hayek, F.A. (1990), Law, Legislation and Liberty, Vol.3, The Political Order of a Free People, University of Chicago Press, Chicago.

Hayek, F.A. (1991), The Fatal Conceit: The Errors of Socialism, The University of Chicago Press, Chicago.

Hazlitt, H. (1964/2012), The Foundations of Morality, New York, Reprinted by the Ludwig von Mises Institute, Auburn, Ala., 2012, available at: http://mises.org/books/foundationsofmorality.pdf

Hirschman, A.O. (1970), Exit, Voice and Loyalty-Responses to Decline in Firms, Organizations and States, Cambridge, Mass, Harvard University Press.

Jamet, J.-F., Mussler, W., De Corte, S. (2011), EU Economic Governance: The French and German Views, Centre for European Studies, Brussels, available at: http://www.martenscentre.eu/sites/default/files/publication-files/eu_ economic_governance.pdf

Juncker, J.-C. et al. (2015), Completing Europe's Economic and Monetary Union, Report, European Commission, available at: http://ec.europa.eu/priorities/economic-monetary-union/docs/5-presidents-report_en.pdf

Kirzner, I.M. (1973), Competition and Entrepreneurship, The University Chicago Press, Chicago.

Kirzner, I.M. (1978), The Perils of Regulation: A Market-Process Approach, University of Miami, School of Law, Coral Gables, Fla.

Kirzner, I.M. (1982), Competition, Regulation, and the Market Process: An "Austrian" Perspective, Cato Policy Analysis, No. 18, available at:. www.cato.org/pub_display.php?pub_id=884, accessed: 26 November, 2009.

Kirzner, I.M. (1997), Entrepreneurial Discovery and the Competitive Market Process: An Austrian Approach, Journal of Economic Literature, Vol. XXV (March), pp. 60-85.

Kok, W. (2006), Facing the Challenge. The Lisbon Agenda for Growth and Employment, Report from the High Level Group, European Commission, Brussels.

Laffont, J.-J., Tirole, J. (1991), The Politics of Government Decision-Making: A Theory of Regulatory Capture, Quarterly Journal of Economics, Vol. 106, No. 4, pp. 1089-1127.

Leeson, P.T., Subrick, J.R. (2006), Robust political economy, Review of Austrian Economics, Vol. 19, No. 2-3, pp. 107-111. 
Mayer, T. (2016), Die Gefahr der Populisten, Frankfurter Allgemeine Zeitung, 04.01.2016, available at: http://www. faz.net/aktuell/wirtschaft/mayers-weltwirtschaft/mayers-weltwirtschaft-die-gefahr-der-populisten-13994661.html Mises, L. von (1920/1990), Economic Calculation in the Socialist Commonwealth, edition of the Ludwig von Mises Institute, Auburn, AL 1990, available at: https://mises.org/pdf/econcalc.pdf

Mises, L. von (1976/1996), A Critique of interventionism: inquiries into present day economic policy and ideology, Revised English translation of the 1976 German new edition (Kritik des Interventionismus: Untersuchengen zur Wirtschaftspolitik und Wirtschaftsideologie der Gegenwart, Stuttgart: Gustav Fischer) translated by H.F. Sennholz, Irvington-on-Hudson, N.Y.: Foundation for Economic Education, 1996, published by the Ludwig von Mises Institute, Auburn, Ala, available at: https://mises.org/etexts/mises/critique/critique.pdf

Moberg, L. (2014), The political economy of special economic zones, Journal of Institutional Economics, available at: http://dx.doi.org/10.1017/S1744137414000241, accessed: June 10, 2014, pp. 1-24.

North, D.C. (1990), Institutions, Institutional Change and Economic Performance, Cambridge University Press, Cambridge.

OECD (2014), OECD Economic Surveys: European Union 2014, OECD Publishing, available at: http://dx.doi. org/10.1787/eco_surveys-eur-2014-en

OECD Statistics, available at: http://epp.eurostat.ec.europa.eu/portal/page/portal/statistics/search_database, several accesses

Olson, M. (1982), The Rise and Decline of Nations: Economic Growth, Stagflation, and Social Rigidities, Yale University Press.

Olson, M. (2000), Power and Prosperity: Outgrowing Communist and Capitalist Dictatorships, Oxford University Press, Oxford.

Pennington, M. (2011a), Robust Political Economy: Classical Liberalism and the Future of Public Policy, Edward Elgar, Cheltenham, UK and Northampton, MA, USA.

Pennington, M. (2011b), Robust Political Economy, Cato's Letter, A Quarterly Message on Liberty, Spring, Vol. 9 , No. 2, accessed at: http://www.cato.org/sites/cato.org/files/pubs/pdf/catosletterv9n2.pdf

Pies, I. (2010), Theoretische Grundlagen demokratischer Wirtschafts- und Gesellschaftspolitik-Der Ansatz von Ludwig von Mises, in: I. Pies, M. Leschke (eds.), Ludwig von Mises' ökonomische Argumentationswissenschaft, Mohr Siebeck, Tübingen, pp. 1-42.

Rodrik, D. (2013), Green Industrial Policy, Oxford Review of Economic Policy, Vol. 30, No. 3, pp. 469-491.

Röpke, W. (1959), Zwischenbilanz der europäischen Wirtschaftsintegration. Kritische Nachlese, in: Ordo, Jahrbuch für die Ordnung in Wirtschaft und Gesellschaft, Vol. 11, pp. 69-94.

Schüller, A. (2006), Wettbewerbs- und Industriepolitik -EU-Integration als Dritter Weg?, in: D. Wentzel (ed.), Ordnungspolitische Aspekte der europäische Integration, Schriften zu Ordnungsfragen der Wirtschaft, Vol. 82, Lucius \& Lucius, Stuttgart, pp. 127-168.

Schüller, A. (2011a), Das fatale Einheitsdenken in der EU. Lehren aus Selbsttäuschungen und Fehlschlägen, Hayek-Vorlesung, ORDO, Bd. 62, pp. 491-515.

Schüller, A. (2011b), Europäische Union: Das fatale Einheitsdenken. FAZ - Frankfurter Allgemeine Zeitung, 03.09.2011, available at: http://www.faz.net/aktuell/wirtschaft/wirtschaftspolitik/europaeische-union-das-fatale-einheitsdenken-11130888-p5.html

Spiegel Online (23.03.2015), 'The Fourth Reich': What Some Europeans See When They Look at Germany, accessed at: http://www.spiegel.de/international/germany/german-power-in-the-age-of-the-euro-crisis-a-1024714.html The Guardian (28.01.2015),We must stop Angela Merkel's bullying-or let the forces of austerity win, available at: http://www.theguardian.com/commentisfree/2015/jan/28/syriza-merkel-economic-greece-europe 
Wagener, H-J., Eger, T. (2014), Europäische Integration: Wirtschaft und Recht, Geschichte und Politik, 3 rd edition, Vahlen, München.

Wohlgemuth, M. (2007), Einheit in Vielfalt: Fünfzig Jahre europäische Ordnungspolitik, FAZ, 17.03.2007, p. 11, available at: http://www.eucken.de/fileadmin/bilder/Dokumente/WohlgemuthPolitikreform.pdf

Wohlgemuth, M. (2012), Wirtschaftsverfassung statt Wirtschaftsregierung! Wirtschaftliche Freiheit, 15 March 2012, available at: http://wirtschaftlichefreiheit.de/wordpress/?p=8825\&amp;print=1

Wohlgemuth, M., Adamovich, I.B. (1999), Systemwettbewerb in der Schweiz: Ein Testfall für das Zusammenspiel von „Exit“, „Voice“"und „Loyalty“, Diskussionsbeitrag 09-99, Max-Planck-Institut zur Erforschung von Wirtschaftssystemen, Jena.

World Bank Database, available at: http://data.worldbank.org

Wruuck, P. (2015), Promoting investment and growth: The role of development banks in Europe, EU Monitor. Global financial markets, Deutsche Bank Research,; available at: https://www.dbresearch.de/PROD/DBR_INTERNET_DE-PROD/PROD0000000000380805/Promoting_investment_and_growth\%3A_The_role_of_devel.pdf, accessed: December 23, 2015. 